\title{
THE ECONOMIC VALUE OF PADDY FIELD BASED ON ITS FACULTIES TO SUPPORT LAND PRODUCTIVITY IN LOWOKWARU SUBDISTRICT, MALANG, EAST JAVA
}

\author{
Rina Suprihati $^{1^{*}}$, Soemarno ${ }^{2}$, Nuhfil Hanani ${ }^{3}$, and S. Gatot Irianto ${ }^{4}$ \\ ${ }^{1)}$ Doctorate Program Fac. of Agriculture, Univ of Brawijaya, Malang 65145, Indonesia \\ ${ }^{2)}$ Soil Science Department, Fac. of Agriculture, Univ. of Brawijaya, Malang 65145, Indonesia \\ ${ }^{3)}$ Social and Economics Department, Fac. of Agriculture, Univ. of Brawijaya, Malang 65145, Indonesia \\ ${ }^{3)}$ Directorate General of Foodcrops, Ministry of Agriculture, Jakarta 12540, Indonesia \\ *Corresponding Author : suprina21@yahoo.com
}

\begin{abstract}
Paddy fields commonly possesses intrinsic natural processes and external benefits that support land productivity. Soil fertility which shown by nutrient contents (Nitrogen, phosporous, potassium and organic matters) gives evidence of the existence of natural processes that occur within the soil that will be lost when land conversion happens. Similarly the external benefit of paddy fields as container of domestic waste compost will be lost too due to the land conversion. These functions and benefits are very important but are not appreciated by society. Giving economic values to paddy fields based on these two faculties will inform the society how valuable paddy fields are as natural resources. The economic valuation method used in this reserch is the Replacement Cost Method (RCM) with mathematical formula as follows NELSsFPUH $=\left(U_{N} \times P_{n}+U_{P} \times P_{p}+\right.$ $\left.\mathrm{U}_{\mathrm{K}} \times \mathrm{P}_{\mathrm{K}}+\mathrm{U}_{\mathrm{BO}} \times \mathrm{P}_{\mathrm{BO}}\right) \times$ A for economic value of paddy field as provider of nutrients contents $(\mathrm{N}, \mathrm{P}, \mathrm{K})$ and organic matters; and NELSPK $=(\mathrm{WK} / \mathrm{KK}) \times \mathrm{PK} \times \mathrm{A}$ for economic value of paddy field as compost container. The research was taken place in 6 sub-subdistricts in Lowokwaru Subdistrict with 205 hectares of paddy fields. The economic value of paddy field is about Rp 133,31 billions for economic value of paddy field as provider of nutrients contents $(\mathrm{N}, \mathrm{P}, \mathrm{K})$ and organic matters; and $\mathrm{Rp}$ 7,76 billions for economic value of paddy field as compost container. For both faculties the average economic value Rp 688,18 million per hectare. Paddy fields in Lowokwaru Subdistricts are very feasible to be protected from conversion due to its satisfactory soil fertility and its potential to be increased, thus it is able to maintain land productivity. Therefore, it is very reasonable to call pady fields as productive open green space in which economic and social activities can be developed.
\end{abstract}

Keywords : Soil Nutrients, Domestic Waste Compost, Economic Value, Paddy Field.

\section{INTRODUCTION}

Paddy field located in the urban area has been known to have a significant role in maintaining the environment quality through its external benefits that are produced indirectly (Yokohari et al., 1997; Matsuno, Hatcho, dan Shindo, 2007). This role makes paddy fields can function as open green space in urban areas. Thus, it is very beneficial for the community when the remaining paddy fields are protected.

As open green spaces, the paddy field ecosystem will serve as conservation areas that sustain hydrological processes; as flood mitigation areas which provide retention basin; as biodiversity development areas; as areas that creates microclimate and pollutant reductions; as public recreation areas; as areas that protect natural, artificial and historical resources; and as disaster mitigation / evacuation areas (Xiao et al., 2005; Natuhara,Y. 2013; Meijide et al., 2017). The paddiy fields can function as provision of employment for marginal communities (farmers and farm labor) in urban areas and continue to generate economic benefit by producing food crops. (Iiyama, Kamada dan Nakagoshi, 2005; Frimawaty et al., 2013; Ndiiri, et al., 2013).

Paddy fields' productivity in urban areas is not secondary compared to productivity in other production areas. One determinant of paddy fields' productivity is soil fertility and its ability to continously provide soil nutrients at certain rate and proportion to support growth and crop production (Poerwowidodo, 1992; Alam et al., 2017). Soil nutrients and organic matter can be used as an 
indicator of soil productivity and fertility that affect plant growth and crop production (Bauer dan Black, 1994; Carter, 2002; Brady dan Weil, 2004; Krull, Skjemstad dan Baldock, 2004)

Paddy fields' productivity can also be affected by application of agrotechnology conducted by farmers in managing their farms (Soemarno, Prasetya dan Kusuma, 2016). To increase paddy fields' productivities, additional organic matter can be given in the form of compost that will act as soil enhancer to improve soil structure as well as soil physical, chemical and biological properties (Ponnamperuma, 1984; Ladha et al., 2000; Dawe et al., 2003; Goyal, et al., 2009; Pambudi, Indrawan dan Soemarno, 2017). Compost can be produced from organic matters derived from domestic waste.

In big cities of most developing countries, large amounts of solid waste or liquid waste resulting from human activities are transported and disposed in landfills (Henry, Yongsheng dan Jun, 2006; Vidanaarachchi, Yuen dan Pilapitiya, 2006; Manga, Forton and Read, 2008; Lombrano, 2009; Guerrero, Maas and Hogland, 2013; Nurita dan Hassan, 2013). The management and disposal of urban solid waste often turn into the most common problem in major cities around the world (Shekdar, 2009; Ngoc dan Schnitzer, 2009; Bel and Fageda, 2010; Xudong, et al., 2010). However, in some major cities, the organic components of municipal waste are recycled and processed into fuel and compost that is used to increase agricultural productivity (Metin, Eröztürk, Neyim, 2003; Sæb $\varnothing$ dan Ferrini, 2006; Wilson, Velis dan Cheeseman, 2006; Weber et al., 2007; Troschinetz dan Mihelcic, 2009; Al-Khatib et al., 2010; Himanen dan Hänninen, 2011; Komilis et al., 2012; Rogge dan deJaeger, 2012; Chen et al., 2016; Taeporamaysamai dan Ratanatamskul, 2016; Vigneswaran, Kandasamy dan Johir, 2016). The application of compost processed from domestic waste to paddy fields not only will increase crop production and land productivity but also will exercise paddy fields as a municipal waste disposal (Levy dan Taylor, 2003; Zheljazkov and Warman, 2004; Hargreaves, Adl dan Warman, 2008; Farrell dan Jones, 2010; Wei et al., 2017).

The problem at hand in regard of protecting the remaining paddy fields is that their environmental services are under appreciated. The natural ability of paddy fields to provide nutrients and organic matters, as well as its potential ability to dispose domestic-waste-compost are very significant yet often underated. The purpose of this study is to measure the economic value of paddy fields as the provider of natural nutrients and as the disposal of domestic-waste-compost.

\section{MATERIAL AND METHODS}

The research was conducted in 205 hectares paddy fields areas of Lowokwaru Subdistrict, Malang City, East Java.

The research was conducted by using quantitative approach through survey method. Data used in this research are primary and secondary data. Primary data were collected by direct sampling in the field and tested in the soil laboratory; while the data related to the cultivation system is obtained through interview with farmers. Secondary data includes data of population, waste production, and spatial plan. Secondary data and information are obtained from various official documents issued by related institutions and various publications. Descriptive analysis is used to explain the ability of paddy field as a provider of natural nutrients and organic matters; and disposal of domestic-waste-compost.

The economic valuation method used in this research is Replacement Cost Method (RCM) with mathematical formula as follows:

A. The Economic Value of Paddy Field as Provider of Natural Soil Nutrient (N, P, K) and Organic Matters (NELSPUH)

$$
\begin{aligned}
& \text { NELSsFPUH }=\left(U_{\mathrm{N}} \times P_{\mathrm{n}}+\mathbf{U}_{\mathrm{P}} \times \mathbf{P}_{\mathrm{p}}+\mathbf{U}_{\mathrm{K}} \times \mathbf{P}_{\mathrm{k}}\right. \\
& \left.+\mathrm{U}_{\mathrm{BO}} \times \mathrm{P}_{\mathrm{BO}}\right) \times \mathrm{A} \text {. } \\
& \text { (1) }
\end{aligned}
$$

Where: NELSFPUH = Economic Value of Paddy Field as Provider of Natural Soil Nutrient (N, P, K) and Organic Matters (Rp); $\mathrm{U}_{\mathrm{N}}=$ the quantity of Nitrogen contained in paddy field $(\mathrm{kg} / \mathrm{ha}) ; \mathrm{P}_{\mathrm{N}}=$ Price of $\mathrm{N}$-contained manufactured fertilizer $(\mathrm{Rp} / \mathrm{Kg}) ; \mathrm{U}_{\mathrm{P}}=$ the quantity of Phosphor contained in paddy field $(\mathrm{kg} / \mathrm{ha}) ; \quad \mathrm{P}_{\mathrm{P}}=$ Price of $\mathrm{P}$-contained manufactured fertilizer $(\mathrm{Rp} \mathrm{kg}) ; \mathrm{U}_{\mathrm{K}}=$ the quantity of Potassium contained in paddy field $(\mathrm{kg} / \mathrm{ha}) ; \quad \mathrm{P}_{\mathrm{K}}=$ Price of $\mathrm{K}$-contained manufactured fertilizer $(\mathrm{Rp} \mathrm{kg})$ ); $\mathrm{U}_{\mathrm{BO}}=$ the quantity of organic matter contained in paddy field $(\mathrm{kg} / \mathrm{ha}) ; \quad \mathrm{P}_{\mathrm{BO}}=$ Price of organic manufactured fertilizer (Rp/ha); $A=$ the acreage of paddy field (ha)

To convert the quantity of soil nutrient $(\mathrm{N}, \mathrm{P}, \mathrm{K})$ and organic matter from laboratory analysis results into field dimension he calculation is made as follows:

1. Nitrogen is expressed in terms of percentage (\%) which means in every 100 grams of soil contains 1 gram of $\mathrm{N}$-total. $\mathrm{N}$ in the soil consists of organic and inorganic $\mathrm{N}$ where the organic $\mathrm{N}$ is much greater $(95 \%)$ than inorganic $\mathrm{N}(5 \%)$. According to Patrick and Reddy (1978) 
about $2-5 \%$ organic-N is converted to inorganic-N annually.

2. Phosphorus is expressed in $\mathrm{mg} / \mathrm{kg}$ unit which means in every $1 \mathrm{~kg}$ of soil contains 1 gram of $P$.

3. Potassium is expressed in me $/ 100 \mathrm{~g}$ which means in every 100 grams of soil contains $1 \mathrm{me}$ of $\mathrm{K}$, where $1 \mathrm{me}$ equals to $39 \mathrm{mg} \mathrm{K}$.

4. Organic matter (BO) expressed in percentage $(\%)$ which means in every 100 grams of soil contains 1 gram of organic matter.
The quantity of nutrients per hectare is calculated within $25-\mathrm{cm}$ depth which is equivalent to $2,500,000 \mathrm{~kg}$ of soil.

The economic value of soil nutrients $(\mathrm{N}, \mathrm{P}, \mathrm{K})$ and organic matters is calculated by converting the quantity of each soil nutrients and organic matter into the quantity of relevant manufactured fertilizers used by local farmers and hence their prices. The related conversion is shown at table 1 below:

Table 1. Conversion of soil nutrients into relevant manufactured fertilizers

\begin{tabular}{|c|c|c|c|c|}
\hline No & $\begin{array}{l}\text { Nutrient } \\
\text { Substance }\end{array}$ & $\begin{array}{c}\text { Name of } \\
\text { Manufactured } \\
\text { fertilizer }\end{array}$ & Active material composition & Fertilizer price per $\mathrm{kg}$ \\
\hline \multirow{2}{*}{1} & organic & Petroganik & $12,30 \% \mathrm{C}, \mathrm{C} / \mathrm{N}$ ratio 15,19 & IDR 1,500 \\
\hline & an-organic & Urea & $46 \% \mathrm{~N}$ & IDR 4,500 \\
\hline 2 & $\mathrm{P}$ & SP36 & $36 \% \mathrm{P} 2 \mathrm{O} 5$ & IDR 5,850 \\
\hline 3 & $\mathrm{~K}$ & $\mathrm{KCl}$ & $60 \% \mathrm{~K} 2 \mathrm{O}$ & IDR 6,000 \\
\hline 4 & Organic material & Organic fertilizer & - & IDR 1,000 \\
\hline \multicolumn{5}{|c|}{$\begin{array}{l}\text { Note : } \\
\text { Value of } \mathrm{N} \text { in Petroganik } 8 \mathrm{gr} / \mathrm{kg} \\
\text { Conversion of } \mathrm{P} \text { to } \mathrm{P} 2 \mathrm{O} 5 \text { is } 2.29 \\
\text { Conversion of } \mathrm{K} \text { to } \mathrm{K} 2 \mathrm{O} \text { is } 1.2\end{array}$} \\
\hline
\end{tabular}

B. The Economic Value of Paddy Field as Domestic Waste Disposal (NELSPK)

NELSPK $=($ WK/KK $) \times$ PK .....

Where: NELSPK = Economic Value of Paddy Field as Domestic Waste Disposal (Rp); WK = The Capacity of Paddy Field to Contain Compost (ton/ha); KK = Coefficient of Domestic Waste turned into Compost $(0,4)$; $\mathrm{PK}=$ The Cost of Domestic Waste Management (Rp/ton).

The cost of domestic waste management in the city of Malang is about Rp 9.386,- per ton. This cost is calculated based on: (the income from municipal retribution of domestic waste management per year + the Government fund of the city waste Management per year)/quantity of waste manage in the same year.

To calculate the potential of paddy field of receiving compost processed from domestic waste, the research used a corresponding the amount of compost apply on SRI (System of Rice Intensification) which is between 14,6 - 20,9 ton/ha/year or at 17,75 ton/ha/year average. Then, the potential compost that can be received by the paddy fields is calculated with the following mathematical formula:

$\mathbf{W K}=\mathbf{P O} \times \mathbf{A}$
Where WK = The capacity of paddy field to receive compost (ton/year); PO = The quantity of compost apply in paddy field (ton/ha/year); $\mathrm{A}=$ the acreage of paddy field (ha)

To calculate the potential of domestic waste produced in one year (365 days) by communities in Lowokwaru Subdistrict, the research used the average amount of waste produced per person in a big city, which is about $0.5 \mathrm{~kg} /$ person/day, while the proportion of domestic waste in a municipal waste is calculated for the city of Malang at 0.7637. Thus, the mathematical formula for the potential amount of domestic waste produced is as follow:

$\mathrm{JSD}=(\mathrm{P} \times \mathrm{xS} \times \mathrm{KK} \times 365) / 1000$

Where JSD $=$ Potential of domestic waste produced (ton/year); $\mathrm{P}=$ Number of population (body); $\mathrm{S}=$ Waste Production (kg/person/day); $\mathrm{KK}=$ Proportion of Domestic Waste in Municipal Waste (0.7637).

\section{RESULT AND DISCUSSION}

Paddy Field As Provider of Natural Soil Nutrient (N, P, K) and Organic Matters 
Soil nutrients are needed by plants to grow and mature in different forms and amounts at every phase of plant growth. There are no less than sixteen essential nutrients that must be sufficiently available for the plant to grow and develop well. Nitrogen $(\mathrm{N})$, phosphorus $(\mathrm{P})$, potassium $(\mathrm{K})$, calcium $(\mathrm{Ca})$, and magnesium $(\mathrm{Mg})$ are subtances that are required by plants in large quantity, known as macro essential nutrients, while other nutrients are called micro essential nutrients because they are needed in small quantities (Zhang and Wang, 2005).

The presence of nutrients and organic matters in soil can occur naturally or unnaturally by adding fertilizer. Farmers apply manufactured fertilizers after considering that nutrients are not available for plants naturally. Three substances that are often given as fertilizers are $\mathrm{N}, \mathrm{P}$, and $\mathrm{K}$ to increase rice production (Hirzel and Rodríguez, 2013). The availability of nutrients in soil and plant tissue is also highly determined by the character and behavior of each nutrient.

Nitrogen is very significant for plant at growth stage. Nitrogen is known as the nutrient that often limits plants' production. (De Datta, Comez and Descalsota, 1988; Kim, 1991; Matsunami, Matsunami and Kokubun, 2009; Artacho, Bonomelli, and Meza, 2009; Hirzel, Pedreros, and Cordero, 2011). Plants suffering from N-deficiency will become dwarfed due to root growth inhibition, while plants with $\mathrm{N}$-excessiveness will easily fall down or catch pest disease.

Another macro substabce that can cause critical in growth stage is phosphorus (P). Lack of phosphorus will affect general plants growth because it cause inhibition to other subtances (Saleque, et al., 1998a; Islam, Islam and Sarker, 2008). Phosphorus is very significant on the growth and production stage of paddy plants, especially for formation of flower and seed, maturing of grain, root development, and resistance to plant diseases.

Potassium (K) is required by plants as enzymes activator. Potassium involves in all the biochemical reactions that take place in plants and thus is known as the most limiting substance. Potassium is not an integral component of a plant, but it is fundamentally required as catalyst of various essential physiological processes. The presence of sufficient available $\mathrm{K}$ in the soil will ensure the plant rigidity. Furthermore, Potassium affects plants to be more resistant to various diseases and stimulate root growth. $\mathrm{K}$ is known as the determinant of production quality. (Saleque et al., 1998b; Soepardi dan Ismunadji, 2007).

In addition to the above three substances, another important component of the soil that benefits to plant growth is the organic matter. This organic matter is a complex and dynamic system, which is materialized from the remains of living material (plants and/or animals) that constantly changing due to biological, physical, and chemical processes that occurs in soil. Organic matters (BO) posseses an important role in determining soil's ability to support crop production, so that when soil is lacking organic matter thus crop production will decrease. The low amount of organic matter in soil informed that the soil has been damaged. Healthy soil contains sufficient organic matters which is important to ensure agricultural productivity (Suriadi dan Nizam 2005).

The existence of nutrients in soil does not mean its continous availability for plants, nevertheless it shows its potential availability. To determine the condition of nutrients in paddy field in Lowokwaru subdistrict, soil analysis was performed. The soil samples were taken when paddy field was at fallow state which were after harvesting of the first planting season and before the commencement of second planting season. At this state, it is assumed that the state of nutrient present in soil are residue from previous season that are not available to plants and not washed away. This condition is considered to be the most natural content of soil nutrients and organic matter at research area. The soil analysis results are listed in Table 2.

Tabel 2. Soil analysis results at Lowokwaru Subdistrict

\begin{tabular}{clccccc}
\hline \multirow{2}{*}{ No } & village & $\begin{array}{c}\mathrm{N} \text {-Total } \\
\%\end{array}$ & $\begin{array}{c}\mathrm{P} \\
\mathrm{mg} / \mathrm{kg}\end{array}$ & $\begin{array}{c}\mathrm{K} \\
\mathrm{me} / 100 \mathrm{~g}\end{array}$ & $\begin{array}{c}\mathrm{BO} \\
\%\end{array}$ & $\mathrm{C} / \mathrm{N}$ \\
\hline 1 & Tasik Madu & 0.14 & 12.70 & 0.19 & 2.13 & 13 \\
2 & Tunggul Wulung & 0.14 & 11.16 & 0.19 & 3.38 & 14 \\
3 & Mojolangu & 0.12 & 4.49 & 0.29 & 3.08 & 15 \\
4 & Jati Mulyo & 0.09 & 2.73 & 0.22 & 2.38 & 15 \\
5 & Merjosari & 0.11 & 9.53 & 0.49 & 2.76 & 15 \\
6 & Tlogomas & 0.10 & 11.21 & 0.03 & 2.65 & 15 \\
\hline
\end{tabular}

Source : primary data analysis

Note : $\mathrm{BO}=$ Organic Matter 
Based on the above soil analysis results, in general $\mathrm{N}$ and $\mathrm{P}$ substances are at low levels, while $\mathrm{K}$ and Organic Materials are at moderate level. This condition occurs because farmers at the research areas apply fertilizer only twice in one planting season. Firstly, at the $15-20$ days after Planting and secondly, at 40 - 45 days after planting with small dosage of fertilizer. However, the $\mathrm{N}$ required by plants could be fulfilled from the microorganism composting process which occurs because the soils have $\mathrm{C} / \mathrm{N}$ ratio of $13-15$. Soils with $\mathrm{C} / \mathrm{N}$ ratio between $10-15$ have the ability to release $\mathrm{N}$ well so that the plant can grow normally (Syekhfani, 2010).

Another favorable quality of soil in research areas is that it contains sufficient organic matter. Healthy soil ideally contains $>5 \%$ organic matter while soil with $<2 \%$ of organic matter is classified as insufficient and considered unhealthy. Organic matter is an integral part of the soil that is very significant to changes in physical, chemical and biological properties of the soil so it becomes a very important indicator of soil qualities (Carter $e t$ $a l, 1997)$.

The existence of sufficient organic matter in soil can reduce the use of manufactured artificial fertilizers because the organic material is a source of nutrient reserves for plants. The advantage of the soil with sufficient organic matter is that it improves its physical condition thus the soil will be easily cultivated. Syekhfani (2010) explains the advantages of soil with rich humus and organic matters include the ability to promptly compost plant residues, the formation solid aggregate, the reduction of soil hardening and crusting, the increase internal drainage, the improvement of internal water flow and the increase in water and nutrient holding capacity. Thus, the rationale of why the paddy fields Lowokwaru subdistrict is still productive as agricultural land is because the soil is very responsive fertilization and any other agritechnological engineering undertaken by the farmers.

To determine the nutrient content of N, P, $\mathrm{K}$ and Organic Matter within every hectare of paddy field, the calulation is shown in Table 3.

Most people are not aware about the benefits of soil's nutrient content in their lives. People should be informed that its is the presence of soil's nutrients that put food on the table via very long intricate processes and services produced by agricultura ecosystem. The Millenium Ecosystem Assessment acknowledged 4 type of services provided by an ecosystem, which are provision services, regulatory services, cultural services and support services. The first three services are directly contacted with human while the last mentioned is the type of service that maintains other services' sustainability. According to Rodriguez et al. (2006) the support services such as soil formation and nutrient cycles, often considered to be an aspect that is not taken into account by the community.

To raise community appreciation of paddy field, they should be introduced to the concept of economic value of paddy field based on its ability to provide natural soil nutrients and organic matter. The environmental and economic impacts of decreasing agricultural soil fertility, due to plant over-absorbtion, erosion, intensive cultivation, low organic matter content, and inadequate fertilization, are real and direct threat to food security and people's livehoods (Bosede, 2010). The economic valuation of a natural resource is an effort to quantitatively calculate (monetary) the benefits of goods or services produced by that specific natural resource, which is based on market value if it exists or non-market value if it does not exist.

Tabel 3. Nutrient content of N, P, K and BO per hectare of Soil

\begin{tabular}{llrrrrr}
\hline \multirow{2}{*}{ No } & \multirow{2}{*}{ Village } & \multicolumn{5}{c}{ Nutrient Content (kg/ha) } \\
\cline { 2 - 6 } & N organic & N anorganic & Phosphor & Pottasium & BO \\
\hline \multirow{2}{*}{1} & Tasik Madu & 3,325 & 175 & 31.75 & 185.25 & 53,250 \\
2 & Tunggul Wulung & 3,325 & 175 & 27.90 & 185.25 & 84,500 \\
3 & Mojolangu & 2,850 & 150 & 11.23 & 282.75 & 77,000 \\
4 & Jati Mulyo & 2,138 & 113 & 6.83 & 214.50 & 59,500 \\
5 & Merjosari & 2,613 & 138 & 23.83 & 477.75 & 69,000 \\
6 & Tlogomas & 2,375 & 125 & 28.03 & 29.25 & 66,250 \\
\hline & Average & 2,771 & 146 & 21.59 & 229.13 & 68,250 \\
\hline
\end{tabular}

Source : primary data analysis

Note $: \mathrm{BO}=$ Organic Matter 
The nutrient cycle is a type of ecosystem service that is difficult to impose monetary value (price) on because there is no market value that can be imposed on this process. This cycle is a manifestation of the existence of highly complex, efficient and sophisticated processes in soil that can not be matched by human fabricated processes, so that no human activity-based service activity can describe the processes occurring within the soil. However, in simple terms, the economic value of the soil's ability to provide nutrients and organic materials is done by using the final product value of the cycle, ie manufactured fertilizer (petroganic, urea, SP36, $\mathrm{KCl}$ and organic fertilizer). The following is the calculation of the amount of nutrients in the soil, the conversion into manufactured fertilizers and the economic value of paddy fields based on their ability to provide natural soil nutrients and organic matter per village in Lowokwaru subdistrict (Table 4 - 9).

Tabel 4. Condition of soil nutrients and its conversion to manufactured fertilizers and its economic value per hectare in Tunggul Wulung

\begin{tabular}{|c|c|c|c|c|c|}
\hline \multirow{2}{*}{ No } & \multicolumn{2}{|c|}{ Nutrient content $(\mathrm{kg} / \mathrm{ha})$} & \multicolumn{2}{|c|}{ Artificial fertilizer $(\mathrm{kg} / \mathrm{ha})$} & \multirow{2}{*}{$\begin{array}{c}\text { Economic value } \\
\text { (IDR/ha) }\end{array}$} \\
\hline & Type & Amount & Name & Amount & \\
\hline \multirow{2}{*}{1} & organik & 3,325 & Petroganik & 410,624 & $615,935,976$ \\
\hline & an-organik & 175 & Urea & 81 & 362,250 \\
\hline 2 & $\mathrm{P}$ & 27.90 & SP36 & 177 & $1,038,229$ \\
\hline 3 & $\mathrm{~K}$ & 185.25 & $\mathrm{KCl}$ & 371 & $2,223,000$ \\
\hline \multirow[t]{2}{*}{4} & Organic material & 84,500 & Organic fertilizer & 84,500 & $84,500,000$ \\
\hline & & & & Amount & $704,059,454$ \\
\hline
\end{tabular}

Source : Primary data Analysis

Tabel 5. Condition of soil nutrients and its conversion to manufactured fertilizers and its economic value per hectare in Tasik Madu

\begin{tabular}{|c|c|c|c|c|c|}
\hline \multirow{2}{*}{ No } & \multicolumn{2}{|c|}{ Nutrient content $(\mathrm{kg} / \mathrm{ha})$} & \multicolumn{2}{|c|}{ Artificial fertilizer (kg/ha) } & \multirow{2}{*}{$\begin{array}{c}\text { Economic value } \\
\text { (IDR/ha) }\end{array}$} \\
\hline & Type & Amount & Name & Amount & \\
\hline \multirow{2}{*}{1} & organik & 3,325 & Petroganik & 410,624 & $615,935,976$ \\
\hline & an-organik & 175 & Urea & 81 & 362,250 \\
\hline 2 & $\mathrm{P}$ & 31.75 & SP36 & 202 & $1,181,497$ \\
\hline 3 & $\mathrm{~K}$ & 185.25 & $\mathrm{KCl}$ & 371 & $2,223,000$ \\
\hline \multirow[t]{2}{*}{4} & Organic material & 53,250 & Organic fertilizer & 53,250 & $53,250,000$ \\
\hline & & & & Amount & $672,952,722$ \\
\hline
\end{tabular}

Source : Primary data Analysis

Tabel 6. Condition of soil nutrients and its conversion to manufactured fertilizers and its economic value per hectare in Mojolangu

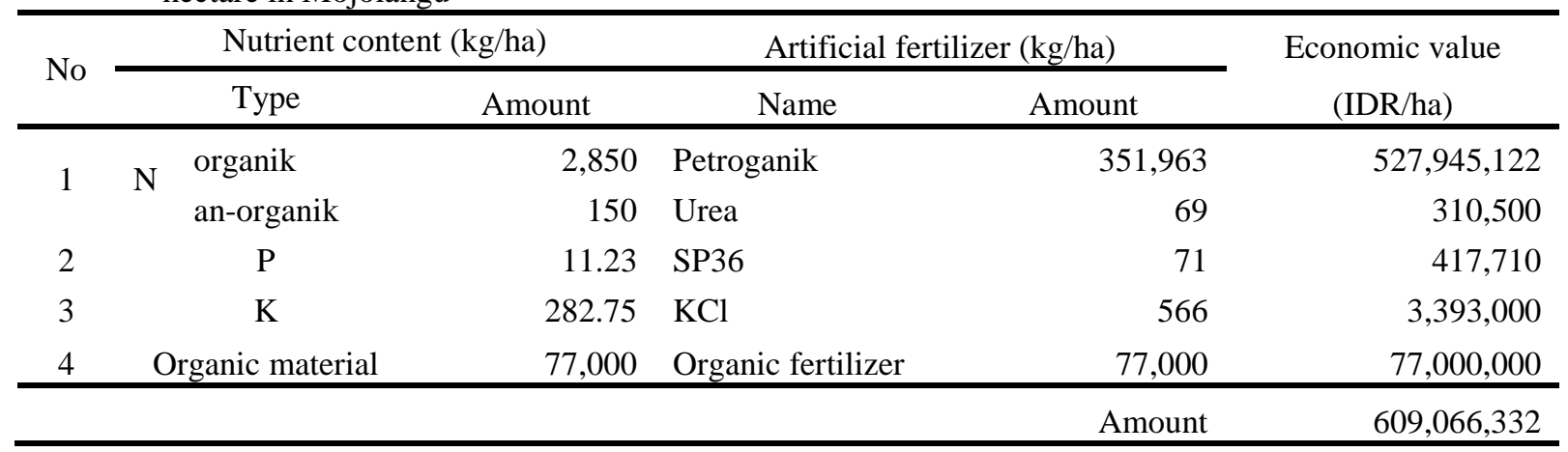

Source : Primary data Analysis 
Tabel 7. Condition of soil nutrients and its conversion to manufactured fertilizers and its economic value per hectare in Merjosari

\begin{tabular}{|c|c|c|c|c|c|}
\hline \multirow{2}{*}{ No } & \multicolumn{2}{|c|}{ Nutrient content $(\mathrm{kg} / \mathrm{ha})$} & \multicolumn{2}{|c|}{ Artificial fertilizer $(\mathrm{kg})$} & \multirow{2}{*}{$\begin{array}{c}\text { Economic value } \\
\text { (IDR) }\end{array}$} \\
\hline & Type & Amount & Name & Amount & \\
\hline \multirow{2}{*}{1} & organik & 2,613 & Petroganik & 322,633 & $483,949,695$ \\
\hline & an-organik & 138 & Urea & 63 & 284,625 \\
\hline 2 & $\mathrm{P}$ & 23.83 & SP36 & 152 & 886,588 \\
\hline 3 & K & 477.75 & $\mathrm{KCl}$ & 956 & $5,733,000$ \\
\hline \multirow[t]{2}{*}{4} & Organic material & 69,000 & Organic fertilizer & 69,000 & $69,000,000$ \\
\hline & & & & Amount & $559,853,908$ \\
\hline
\end{tabular}

Source : Primary data Analysis

Tabel 8. Condition of soil nutrients and its conversion to manufactured fertilizers and its economic value per hectare in Tlogomas

\begin{tabular}{|c|c|c|c|c|c|}
\hline \multirow{2}{*}{ No } & \multicolumn{2}{|c|}{ Nutrient content $(\mathrm{kg} / \mathrm{ha})$} & \multicolumn{2}{|c|}{ Artificial fertilizer $(\mathrm{kg} / \mathrm{ha})$} & \multirow{2}{*}{$\begin{array}{c}\text { Economic value } \\
\text { (IDR/ha) }\end{array}$} \\
\hline & Type & Amount & Name & Amount & \\
\hline \multirow{2}{*}{1} & organik & 2,375 & Petroganik & 293,303 & $439,954,268$ \\
\hline & an-organik & 125 & Urea & 58 & 258,750 \\
\hline 2 & $\mathrm{P}$ & 28.03 & SP36 & 178 & $1,042,880$ \\
\hline 3 & $\mathrm{~K}$ & 29.25 & $\mathrm{KCl}$ & 59 & 351,000 \\
\hline \multirow[t]{2}{*}{4} & Organic material & 66,250 & Organic fertilizer & 66,250 & $66,250,000$ \\
\hline & & & & Amount & $507,856,899$ \\
\hline
\end{tabular}

Source : Primary data Analysis

Tabel 9. Condition of soil nutrients and its conversion to manufactured fertilizers and its economic value per hectare in Jati Mulyo

\begin{tabular}{|c|c|c|c|c|c|}
\hline \multirow{2}{*}{ No } & \multicolumn{2}{|c|}{ Nutrient content $(\mathrm{kg} / \mathrm{ha})$} & \multicolumn{2}{|c|}{ Artificial fertilizer (kg/ha) } & \multirow{2}{*}{$\begin{array}{c}\text { Economic value } \\
\text { (IDR/ha) }\end{array}$} \\
\hline & Type & Amount & Name & Amount & \\
\hline \multirow{2}{*}{1} & organik & 2,138 & Petroganik & 263,973 & $395,958,841$ \\
\hline & an-organik & 113 & Urea & 52 & 232,875 \\
\hline 2 & $\mathrm{P}$ & 6.83 & SP36 & 43 & 253,975 \\
\hline 3 & $\mathrm{~K}$ & 214.50 & $\mathrm{KCl}$ & 429 & $2,574,000$ \\
\hline \multirow[t]{2}{*}{4} & Organic material & 59,500 & Organic fertilizer & 59,500 & $59,500,000$ \\
\hline & & & & Amount & $458,519,692$ \\
\hline
\end{tabular}

Source : Primary data Analysis

The economic value of paddy field in Tunggul Wulung sub-village is highest compared to the other five villages because it has the highest soil nutrient and organic matter content. In comparison to nutrient and organic matter conditions in Tasik Madu sub-village (the second highest), the difference lies in the content of organic matter. The average economic value of paddy field as a provider of natural soil nutrients and organic matter per hectare in Lowokwaru subdistrict is about $\mathrm{Rp}$ 585.38 million. This value indicates the economic loss per hectare of paddy fields converted to nonagricultural use. This is information is something that community, even farmers as the person responsible in the field, does not aware of.
The calculation of paddy field as the provider of natural soil nutrients and organic matter in Lowokwaru subdistrict was conducted in 6 villages with acreages approximately reached 205 hectares, which divided into 131 hectares in Tasik Madu, 32 hectares in Tunggul Wulung, 12 hectares in Mojolangu, 12 hectares in Merjosari, 11 hectares in Jatimulyo and 7 hectares in Tlogomas. The total economic value for each village is based on the area of paddy fields in coresponding village. The total economic value of paddy field in Tasik Madu is the highest, reaching up to $\mathrm{Rp} 88.16$ billion because this village covers the most extensive paddy field area as (Figure 1). 


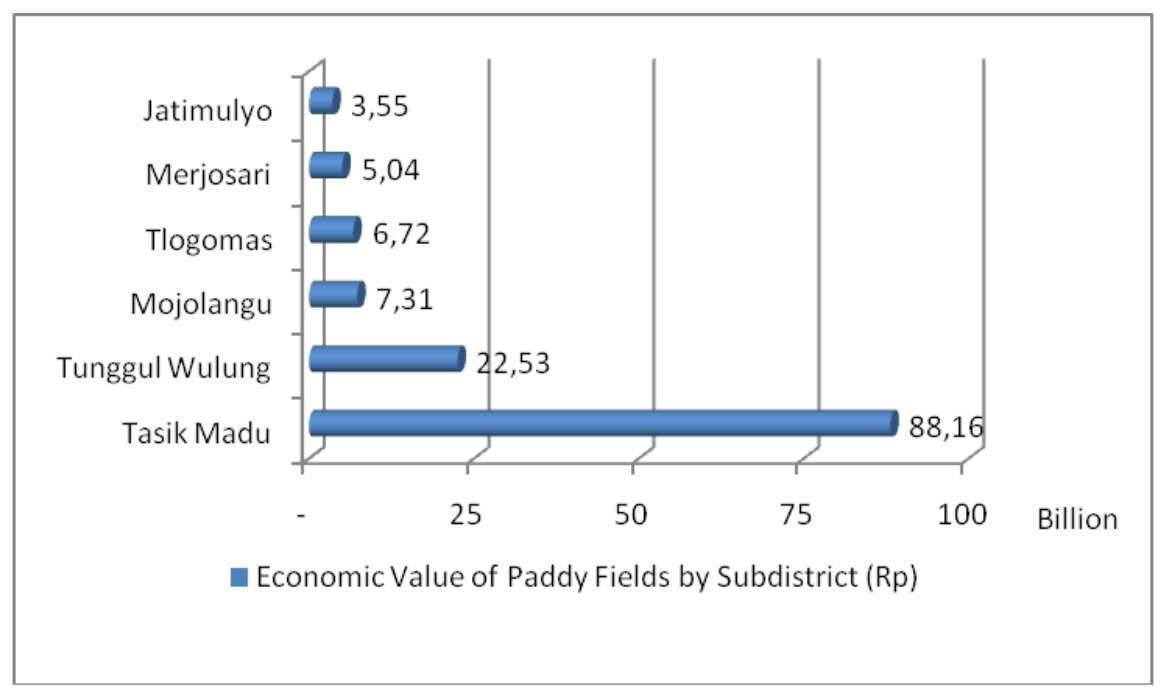

Figure 1. Economy value of paddy field as provider of natural soil nutrients $(\mathrm{N}, \mathrm{P}, \mathrm{K})$ and organic matter in lowokwaru subdistrict

The ability of paddy fields to provide natural soil nutrients $(\mathrm{N}, \mathrm{P}, \mathrm{K})$ and organic matter directly influences the condition of soil fertility and eventually determinded its productivity. Hence, land conversion which disregards soil fertility will directly affects the condition of food production. Irawan (2008) explained about two type of impacts caused by paddy field conversion to food production. The first is that this impact is considered permanent because there is no turning back when paddy field is converted to nonagricultural use (irreversible); and then, it is considered to be progressive because it is harming the opportunity of production increase (due to new farming technology or farming efficiency) that can only be adopted if the paddy fields stays as productive agricultural land.

\section{The Economic Value of Paddy Field as Disposal of Domestic Waste}

The 205 hectares of paddy fields in Lowokwaru subdistrict when managed as System of Rice Intensification (SRI) cultivation system will provide a high potential for compost absorption. In some areas of Indonesia, SRI cultivation methods have shown to increase productivity compared to conventional rice cultivation. Sato (2007) stated that SRI cultivation method which developed in eastern part of Indonesia could increase land productivity from 5.0 ton/ha to 7.4 ton/ha.

The Ministry of Agriculture (2013) defines SRI as an approach to rice cultivation practices that emphasizes on soil, crop and water management through group empowerment and local wisdom which is based on environmentally friendly activities. In SRI concept paddy crop is treated as living organism and not as a food-generating machine that can be manipulated. Anugrah et.al. (2008) stated general adoption of SRI undertaken by farmers of Ecological Rice Farming Community in Garut and Ciamis constitued these 3 essential elements: (1) healthy soil and organic matter management; (2) optimal management of crop potential; and (3) good and orderly water management.

Farmers in Lowokwaru subdistrict are still applying conventional rice cultivation with the use of inorganic fertilizers and minimum compost addition. If farmers in Kecamatan Lowokwaru apply SRI rice cultivation with compost volume of 14.6 - 20.9 tons per hectare per year (as applied by farmers of Ecological Rice Farming community in Garut and Ciamis). Thus, based on equation (3) the area of paddy field in research area will need compost as seen as Table 10. 


\begin{tabular}{llrrrr}
\hline \multirow{2}{*}{ No } & \multicolumn{2}{c}{ Village } & Paddy Field area & \multicolumn{3}{c}{ Compost need (ton/ha/year) } \\
\cline { 3 - 5 } & & ha & 14.6 (minimum) & 20.9 (maximum) & Average \\
\hline 1 & Tasik Madu & 131.00 & $1,912.60$ & $2,737.90$ & $2,325.25$ \\
2 & Tunggul Wulung & 32.00 & 467.20 & 668.80 & 568.00 \\
3 & Jatimulyo & 7.00 & 102.20 & 146.30 & 124.25 \\
4 & Tlogomas & 12.00 & 175.20 & 250.80 & 213.00 \\
5 & Merjosari & 12.00 & 175.20 & 250.80 & 213.00 \\
6 & Mojolangu & 11.00 & 160.60 & 229.90 & 195.25 \\
& Average & 34.17 & 498.83 & 714.08 & 606.46 \\
\hline
\end{tabular}

Source : Primary Data analysis

Based on quantity of compost needed per hectare paddy field, then the total compost need for the whole area of paddy fields and its economic value in Lowokwaru subdistrict is shown in table 11. The economic value of paddy field based on its capability to receive compost is calculated using equation (2).

Table 11. Potential Compost Needs for All paddy Fields and Economic Value of Paddy Field as Compos Container in Kecamatan Lowokwaru

\begin{tabular}{rlrrrrrr}
\hline \multirow{2}{*}{ No } & \multirow{2}{*}{ Village } & \multicolumn{3}{c}{$\begin{array}{c}\text { Total compost need } \\
\text { (000 ton/year) }\end{array}$} & \multicolumn{3}{c}{$\begin{array}{c}\text { Economic value } \\
\text { (000.000 IDR) }\end{array}$} \\
\cline { 3 - 8 } & & Minimum* & Maximum** & Average & Minimum & Maximum & Average \\
\hline 1 & Tasik Madu & 250.55 & 358.66 & 304.61 & $5,879.17$ & $8,416.07$ & $7,147.62$ \\
& Tunggul & & & & & & \\
2 & Wulung & 14.95 & 21.40 & 18.18 & 350.81 & 502.19 & 426.50 \\
3 & Jatimulyo & 0.72 & 1.02 & 0.87 & 16.79 & 24.03 & 20.41 \\
4 & Tlogomas & 2.10 & 3.01 & 2.56 & 49.33 & 70.62 & 59.98 \\
5 & Merjosari & 2.10 & 3.01 & 2.56 & 49.33 & 70.62 & 59.98 \\
6 & Mojolangu & 1.77 & 2.53 & 2.15 & 41.45 & 59.34 & 50.40 \\
\hline & Average & 45.36 & 64.94 & 55.15 & $1,064.48$ & $1,523.81$ & $1,294.15$ \\
& Total & 272.19 & 389.64 & 330.91 & $6,386.89$ & $9,142.87$ & $7,764.88$ \\
\hline
\end{tabular}

Note : (*) Based on compost quantity of 14,6 ton/ha/year; (**) based on compost quantity of 20,9 ton/ha/year.

Paddy fields have the maximum potential to receive 389,640 tons of compost per year with economic value reaching $\mathrm{Rp} 9.14$ trillion. This economic advantage can only be achieved if the Lowokwaru sub-subdistricts community are willing to select, sort and process domestic waste that they produce to turn them into compost. If the need for compost can be fulfilled from recycling local domestic waste, then paddy field within the area will be the solution to waste management problems in the city Malang.

The raw material for composting comes locally and is quite abundant and cheap (Sulistyawati et al., 2009). The composting raw material from domestic waste is highly dependent on the number of population and the rate of waste they generate. Damanhuri (2006) calculates the waste generation unit for a big city is about $2-2.5$ litre/person/hari or $0.4-0.5 \mathrm{~kg} /$ person/day which become the basis of planning, design, and potential of waste management towards zero waste. Based on the above assumption, it is estimated that the waste generation at the research location is about 0.5 $\mathrm{kg} /$ person/day, the calculation of waste generation and the quantity of domestic waste is based on equation (4) in Lowokwaru Subdistrict are listed in Table 12.

Table 12. Waste Generation Rate and Estimated Quantity Domestic Waste Volume in Lowokwaru Subdistrict 


\begin{tabular}{rlccc}
\hline No & Village & $\begin{array}{c}\text { Number of population } \\
\text { (body) }\end{array}$ & $\begin{array}{c}\text { Rate of Waste } \\
\text { Generation * (kg/day) }\end{array}$ & $\begin{array}{c}\text { Quantity of Domestic } \\
\text { waste * } \\
\text { (kg/day) }\end{array}$ \\
\hline 1 & Tasik Madu & 6,281 & 3,141 & 2,398 \\
2 & Tunggul Wulung & 6,701 & 3,351 & 2,559 \\
3 & Jatimulyo & 20,332 & 10,166 & 7,764 \\
4 & Tlogomas & 13,450 & 6,725 & 5,136 \\
5 & Merjosari & 16,729 & 8,365 & 6,388 \\
6 & Mojolangu & 24,481 & 12,241 & 9,348 \\
\hline
\end{tabular}

Source : secondary data analysis.

Domestic waste into compost is a simple process that can be done on individual householda scale or on communal scale. However, in order to asure that domestic waste is free from the harmful effects of chemicals, then compost quality testing is required (Domingo and Nadal, 2009; Smith, 2009; Sudrajat, 2015). The management of composting from domestic waste requires commitment and participation from surrounding community. Direct community participation will be presented by the amount of organic waste that is sorted and collected at collection point. The higher the level of community participation, the more organic waste will be sorted and collected. Considering the level of community participation in the sorting and collection of organic waste, it is assumed that not all domestic waste can be processed into compost, thus in this research there 3 assumptions of community participation, which are $75 \%, 50 \%$ and $25 \%$ participation. The conversion rate of waste processed into compost is 0.4 which is based on the pilot project of market-waste management in Yogyakarta so that the potential quantity of compost that can be produced by the community in each subsistrict is shown in Table 13.

Tabel 13. Potential quantity of domestic waste and compost (ton/year)

\begin{tabular}{lrrrrrr}
\hline \multirow{2}{*}{ SubDistric } & \multicolumn{3}{c}{ Domestic waste } & \multicolumn{3}{c}{ Compost } \\
\cline { 2 - 7 } & \multicolumn{1}{c}{$75 \%$} & $50 \%$ & $25 \%$ & $75 \%$ & $50 \%$ & $25 \%$ \\
\hline Tasik Madu & 656.56 & 437.71 & 218.85 & 262.62 & 175.08 & 87.54 \\
Tunggul Wulung & 700.47 & 466.98 & 233.49 & 280.19 & 186.79 & 93.40 \\
Jatimulyo & $2,125.33$ & $1,416.89$ & 708.44 & 850.13 & 566.76 & 283.38 \\
Tlogomas & $1,405.95$ & 937.30 & 468.65 & 562.38 & 374.92 & 187.46 \\
Merjosari & $1,748.71$ & $1,165.80$ & 582.90 & 699.48 & 466.32 & 233.16 \\
Mojolangu & $2,559.03$ & $1,706.02$ & 853.01 & $1,023.61$ & 682.41 & 341.20 \\
\hline \multicolumn{1}{c}{ Total } & $10,918.62$ & $7,279.08$ & $3,639.54$ & $4,367.45$ & $2,911.63$ & $1,455.82$ \\
\hline \multicolumn{1}{c}{ Sot }
\end{tabular}

Source : secondary data analysis

More populated villages have the potential to produce more compost, in contrast they have relatively smaller area of paddy fields which resulting in compost overproduction. The illustration of the ratio of compost needs (based on mean value) and compost production can be seen in Figure 2. 


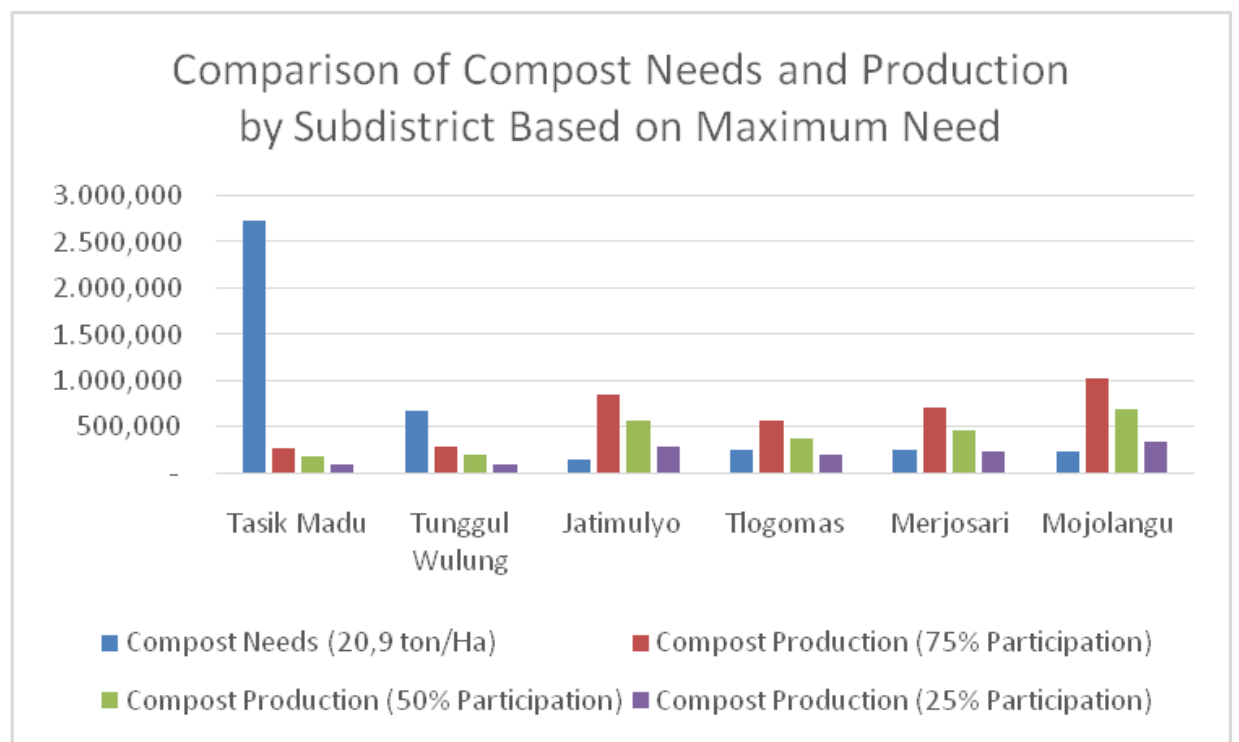

Figure 2. Comparison of Needs and Production of Compost per village

There are two types of situation in Lowokwaru subdistrict based on the ratio of compost needs and compost production, ie villages with insufficient compost production (Tasik Madu and Tunggul Wulung) and the other is villages with excess compost production (Jatimulyo, Tlogomas, Merjosari and Mojolangu). Under these circumstances, the sub-villages in the first situation will require additional compost, while other subdistrit in the second situation can send their compost production elsewhere. To bridge these two situations, there should be a compost management system in Lowokwaru that works across village with tasks includes waste collection, compost processing and distribution.

The total need of compost in Lowokwaru village reach to the quantity of $330,913.25$ tons per year while local production only amounted to $75,722.82,50,481.88$ and $25,240.94$ tons per year at community participation level $75 \%, 50 \%$ and $25 \%$ respectively. To meet the needs of compost for the whole area of paddy field then additional compost should comes from other villages that do not have paddy field. Thus, these village should be encourage to adopt composting programs as well.

In the end, the function of paddy field as disposal of domestic waste holds multi impacts to the community, socially it affects the society behavior to handling waste, economically it directly increases land production and profit of rice farming, and indirectly it reduces the budget for waste management Kota Malang.

\section{The Total Economic Value of Paddy field as Provider of Natural Soil Nutrient and Organic Matter and DisposaL of Domestic Waste}

The total economic value calculated from two intrinsic functions of paddy fields based on its faculties to support land productivity (Table 14). Based on the calculation below, each hectare of paddy field in the research area has an average economic value of about $\mathrm{Rp} 688.18$ million.

Table 14. The total economic value of paddy field in Lowokwaru subdistrict (Rp million)

\begin{tabular}{clrrr}
\hline NO & \multicolumn{1}{c}{ Village } & NELSPUH & NELSPK $*$ & \multicolumn{1}{c}{ TOTAL } \\
\hline 1 & Tasik Madu & $88,156.81$ & $7,147.62$ & $95,304.43$ \\
2 & Tunggul Wulung & $22,529.90$ & 426.50 & $22,956.40$ \\
3 & Mojolangu & $7,308.80$ & 20.41 & $7,329.21$ \\
4 & Merjosari & $6,718.25$ & 59.98 & $6,778.23$ \\
5 & Jatimulyo & $5,043.72$ & 59.98 & $5,103.70$ \\
6 & Tlogomas & $3,555.00$ & 50.40 & $3,605.40$ \\
7 & Average & $22,055.19$ & $1,294.15$ & $23,512.90$ \\
\hline & Total & $133,312.48$ & $7,764.88$ & $141,077.37$ \\
\hline
\end{tabular}

Note :

* The average of economic value of paddy field as disposal of domestic waste 


\section{CONCLUSION}

The existence of 205 hectares of paddy fields in Lowokwaru subdistrict holds the economic value of about Rp 688.18 million/ha based on its intrinsic benefit of provider natural soil nutrient and organic matter, and disposal of domestic waste.

The ability of paddy fields to provide natural soil nutrients and organic matter is only beneficial if the paddy fields are not converted into other land use.

The potential of paddy fields to receive compost processed from domestic waste is one solution to recurring urban problem of waste management.

Paddy fields in the city of Malang are feasible to be protected as agricultural land because of the current state of soil fertility which is potential to support high productivity.

Thus, with the existing environmental and economic benefits derived, paddy field in the city Malang can serve as productive open green space.

\section{ACKNOWLEDGEMENT}

This article is a inseparable part of final dissertation as requirement for finishing Doctorate Program of Agricultural Science, Faculty of Agriculture, University of Brawijaya, Malang, Indonesia. Thank you to the Ministry of Agriculture for the financial support (scholarship).

\section{REFERENCES}

Alam,M.J., E. Humphreys, M.A.R. Sarkar, S.Yadav. 2017 . Intensification and diversification increase land and water productivity and profitability of rice-based cropping systems on the High Ganges River Floodplain of Bangladesh. Field Crops Research, 209: 10-26

Al-Khatib,I.A., M.Monou, A.S.F.A. Zahra, H.Q.Shaheen, D.Kassinos. 2010. Solid waste characterization, quantification and management practices in developing countries. A case study: Nablus village Palestine. Journal of Environmental Management, 91(5): 1131-1138

Anugrah. 2008. Gagasan dan Implementasi System of Rice Intensification (SRI) dalam Kegiatan Budidaya Padi Ekologis. Jurnal Analisis Kebijakan Pertanian, 6 (1): 7599.
Artacho, P., C. Bonomelli, and F. Meza. 2009. Nitrogen application in irrigated rice growth in Mediterranean conditions: Effects on grain yield, dry matter production, nitrogen uptake, and nitrogen use efficiency. Journal of Plant Nutrition 32:1574-1593.

Bauer, A. and A.L.Black. 1994. Quantification of the effect of soil organic matter content on soil productivity. Am. J. Soil Sci. Soc., 5: 185-193.

Bel,G. and X.Fageda. 2010. Empirical analysis of solid management waste costs: Some evidence from Galicia, Spain. Resources, Conservation and Recycling, 54(3): 187193.

Bosede, A.J. 2010. Economic Assessment of fertilizer use and integrated practices for environental sustainability and agricultural productivity in Sudan Savannah Zone Nigeria. African Journal of agricultural Research, 5(5): 338-343

Brady, N.C. and R.R. Weil. 2004. Elements of the Nature and Properties of Soils. 2nd ed. Pearson Education, Inc., Upper Saddle River, NJ.

Carter, M.R. 2002. Soil Quality for sustainable land management: Organic matter and aggregation interactions that maintain soil function. Agron. J., 94: 38-47.

Carter, M.R., E.G. Gregorich, D.W. Anderson, J.W. Doran, H.H. Janzen, and F.J. Pierce. 1997. Concepts of Soil Quality and their Acton, D.F. 1991. Concepts and Criteria of Soil Quality in the Context Significance. p. 119.

Chen,P., Q.Xie, M.Addy, W.Zhou, Y.Liu, Y.Wang, Y.Cheng, K.Li, R.Ruan. 2016. Utilization of municipal solid and liquid wastes for bioenergy and bioproducts production. Bioresource Technology, 215: 163-172

Damanhuri, E. and T. Padmi. 2006. Diktat Kuliah Pengelolaan Sampah. Institut Teknologi Bandung, Bandung.

Dawe,D., A.Dobermann, J.K.Ladha, R.L.Yadav, L.Bao, R.K.Gupta, P.Lal, G.Panaullah, O.Sariam, Y. Singh, A.Swarup, Q.-X. Zhen. 2003. Do organic amendments improve yield trends and profitability in 
intensive rice systems? Field Crops Research 83 (2003) 191-213.

De Datta,S.K., K.A.Comez, and J.Descalsota. 1988. Changes in yield response to major nutrients and in soil fertility under intensive rice cropping. Soil Sci., 146: 350-358.

Domingo, J.L. and M.Nadal. 2009. Domestic waste composting facilities: A review of human health risks. Environment International, 35(2): 382-389.

Farrell,M. and D.L.Jones. 2010. Use of composts in the remediation of heavy metal contaminated soil. Journal of Hazardous Materials, 175(1-3): 575-582

Frimawaty,E., A.Basukriadi, J.A.Syamsu, T.E. Budhi Soesilo. 2013. Sustainability of Rice Farming based on Eco-Farming to Face Food Security and Climate Change: Case Study in Jambi Province, Indonesia. Procedia Environmental Sciences, 17: 5359

Goyal,S., D.Singh, S.Suneja and K.K. Kapoor. 2009. Effect Of Rice Straw Compost On Soil Microbiological Properties And Yield Of Rice. Indian J. Agric. Res., 43(4) : 263 $-268$

Guerrero,L.A., G.Maas and W.Hogland. 2013. Solid waste management challenges for cities in developing countries. Waste Management, 33(1): 220-232.

Hargreaves,J.C., M.S.Adl and P.R. Warman. 2008. A review of the use of composted municipal solid waste in agriculture. Agriculture, Ecosystems \& Environment, 123(1-3): $1-14$

Henry,R.K., Z.Yongsheng and D.Jun. 2006. Municipal solid waste management challenges in developing countries Kenyan case study. Waste Management, 26(1): 92-100

Himanen,M. and K.Hänninen. 2011. Composting of bio-waste, aerobic and anaerobic sludges Effect of feedstock on the process and quality of compost. Bioresource Technology, 102(3): 2842-2852.

Hirzel,J. and F. Rodríguez 2013. Increasing nitrogen rates in rice and its effect on plant nutrient composition and nitrogen apparent recovery . Chilean J. Agric. Res., 73(4): $\mathrm{xx}$.

Hirzel,J., A.Pedreros, and K.Cordero. 2011. Effect of nitrogen rates and split nitrogen fertilization on grain yield and its components in flooded rice. Chilean Journal of Agricultural Research, 71: 437444.

Iiyama,N., M. Kamada, N. Nakagoshi. 2005. Ecological and social evaluation of landscape in a rural area with terraced paddies in southwestern Japan. Landscape and Urban Planning, 73(1): 60-71.

Islam, M.A., M. R. Islam and A.B.S. Sarker. 2008. Effect of Phosphorus on Nutrient Uptake of Japonica and Indica Rice. Agric Rural Dev., 6(1\&2): 7-12.

Kim H.T. 1991. Dasar-Dasar Kimia Tanah . Gajah Mada University Press. Yogyakarta

Komilis, D., A. Evangelou, G. Giannakis and C.Lymperis. 2012. Revisiting the elemental composition and the calorific value of the organic fraction of municipal solid wastes. Waste Management, 32(3): 372-381.

Krull, E., J.Skjemstad and J.Baldock. 2004. Functions of Soil Organic Matter and the Effect on Soil Properties: A Literature Review. Report for GRDC and CRC for Greenhouse Accounting. CSIRO Land and Water Client Report. Adelaide: CSIRO Land and Water.

Ladha,J.K., D.Dawe, T.S.Ventura, U.Singh, W.Ventura, I.Watanabe. 2000. Long-term effects of urea and green manure on rice yields and nitrogen balance. Soil Sci. Soc. Am. J., 64: 1993-2001.

Levy,J.S. and B.R.Taylor. 2003. Effects of pulp mill solids and three composts on early growth of tomatoes. Bioresource Technology, 89(3): 297-305

Lombrano,A. 2009. Cost efficiency in the management of solid urban waste. Resources, Conservation and Recycling, 53(11): 601-611.

Manga,V.E., O.T.Forton and A.D.Read. 2008. Waste management in Cameroon: A new policy perspective? Resources, 
Conservation and Recycling, 52(4): 592600.

Matsunami, M., T. Matsunami, and M. Kokubun. 2009. Growth and yield of new rice for Africa (NERICAs) under different ecosystems and nitrogen levels. Plant Production Science 12:381-389.

Matsuno,Y., N.Hatcho, S.Shindo. 2007. Water transfer from agriculture to urban domestic users: a case study of the Tone River Basin, Japan. Paddy Water Environment, 5: 239-246.

Meijide,A., C. Gruening, I. Goded, G. Seufert, A. Cescatti. 2017. Water management reduces greenhouse gas emissions in a Mediterranean rice paddy field. Agriculture, Ecosystems \& Environment, 238: $168-178$

Metin,E., A.Eröztürk, C.Neyim. 2003. Solid waste management practices and review of recovery and recycling operations in Turkey. Waste Management, 23(5): 425432. (2003)

Natuhara,Y. 2013. Ecosystem services by paddy fields as substitutes of natural wetlands in Japan. Ecological Engineering, 56: 97106.

Ndiiri,J.A., B.M. Mati, P.G. Home, B. Odongo, N. Uphoff. 2013. Adoption, constraints and economic returns of paddy rice under the system of rice intensification in Mwea, Kenya. Agricultural Water Management, 129: 44-55.

Ngoc,U.N. and H.Schnitzer. 2009. Sustainable solutions for solid waste management in Southeast Asian countries. Waste Management, Volume 29, Issue 6, June 2009, Pages 1982-1995

Nurita, A.T. dan A.A. Hassan. 2013. Filth flies associated with municipal solid waste and impact of delay in cover soil application on adult filth fly emergence in a sanitary landfill in Pulau Pinang, Malaysia. Bulletin of Entomological Research, 103: 296-302

Pambudi,D., M. Indrawan and Soemarno. 2017. Pengaruh Blotong, Abu Ketel, Kompos Terhadap Ketersediaan Fosfor Tanah Dan Pertumbuhan Tebu Di Lahan Tebu Pabrik
Gula Kebon Agung, Malang. Jurnal Tanah dan Sumberdaya Lahan 4 (1), 431-443.

Poerwowidodo. 1992. Telaah Kesuburan Tanah. Angkasa. Bandung

Ponnamperuma, F.N. 1984. Straw as a source of nutrients for wetland rice. In: Organic Matter and Rice. International Rice Research Institute, Manila, Philippines, pp. 117-136.

Rodriguez, J.P., T.D.Beard Jr, E.M. Bennet, G.S. Cumming, S.J. Cork, J. Agard, A.P. Dobson and G.D.Peterson. 2006. Tradeoffs Across Space, Time and Ecosystem Services. Ecology and Society, 11(1):28

Rogge, N. and S. deJaeger. 2012. Evaluating the efficiency of municipalities in collecting and processing municipal solid waste: A shared input DEA-model. Waste Management, 32(10): 1968-1978.

Sæbø,A., and F.Ferrini. 2006. The use of compost in urban green areas - A review for practical application. Urban Forestry \& Urban Greening, 4(3-4): 159-169

Saleque, M. A., M.J.Abedin, G.M.Panaullah and N.I.Bhuiyan. 1998a. Yield and phosphorus efficiency of some lowland rice varieties at different levels of soil-available phosphorus. Commun. Soil Sci Plant Anal., 29: 2905-2916.

Saleque, M.A., P.K.Saha, G.M.Panaullah, and N.I.Bhuiyan. 1998b. Response of wetland rice to potassium in farmers' fields of the Barind tract of Bangladesh. J. Plant Nutri., 21: 39-47.

Sato,S. 2007. SRI Mampu Tingkatkan Produksi Padi Nasional. http:www.kapanlagi.com/h/0000182474.ht ml.

Shekdar, A.V. 2009. Sustainable solid waste management: An integrated approach for Asian countries. Waste Management, 29 (4): $1438-1448$

Smith, S.R. 2009. A critical review of the bioavailability and impacts of heavy metals in municipal solid waste composts compared to sewage sludge. Environment International, 35(1): 142-156. 
Soemarno, B. Prasetya and Z. Kusuma. 2016. Pengelolaan Sumberdaya Lahan Sawah Berkelanjutan. Buku 1 (lahan sawah), Jurusan Tanah, FP UB. 240 hal

Soepardi, G. and M. Ismunadji. 2007. Harkat Kalium Tanah. IPB Press. Bogor.

Sudrajat. 2015. Mengenal Lahan sawah dan memahami Multifungsinya Bagi Manusia dan Lingkungan. Gadjah Mada University Press. Yogyakarta.

Sulistyawati, E. and R. Nugraha. 2009. Efektivitas Kompos Sampah Perkotaan Sebagai Pupuk Organik dalam Meningkatkan Produktivitas dan Menurunkan Biaya Produksi Budidaya Padi. Sekolah Ilmu dan Teknologi Hayati - Institut Teknologi Bandung.

Suriadi, A. and M. Nazam. 2005. Penilaian Kualitas Tanah Berdasarkan Kandungan Bahan Organik. Nusa Tenggara Barat : Balai Pengkajian Teknologi Pertanian NTB.

Syekhfani. 2010. Hubungan Hara Tanah, Air dan Tanaman. Dasar-Dasar Pengelolaan Tanah Subur Berkelanjutan. Edisi ke-2

Taeporamaysamai, O. and C. Ratanatamskul. 2016. Co-composting of various organic substrates from municipal solid waste using an on-site prototype vermicomposting reactor. International Biodeterioration \& Biodegradation, 113: 357-366

Troschinetz, A.M. and J.R.Mihelcic. 2009. Sustainable recycling of municipal solid waste in developing countries. Waste Management, 29 (2): 915-923

Vidanaarachchi,C.K., S.T.S.Yuen, S.Pilapitiya. 2006. Municipal solid waste management in the Southern Province of Sri Lanka: Problems, issues and challenges. Waste Management, 26 (8): 920-930

Vigneswaran,S., J. Kandasamy, M.A.H. Johir. 2016. Sustainable Operation of Composting_in Solid_Waste_ Management.
Procedia Environmental Sciences, 35: 408415

Weber,J., A.Karczewska, J. Drozd, M. Licznar, S. Licznar, E. Jamroz, A. Kocowicz. 2007. Agricultural and ecological aspects of a sandy soil as affected by the application of municipal solid waste composts. Soil Biology and Biochemistry, 39(6): 12941302

Wei,Y., J.Li, D. Shi, G.Liu, and T.Shimaoka. 2017. Environmental challenges impeding the composting of biodegradable municipal solid_waste: A critical review. Resources, Conservation and Recycling, 122: 51-65.

Wilson,D.C., C.Velis, C.Cheeseman. 2006. Role of informal sector recycling in waste management in developing countries. Habitat International, 30(4): 797-808

Xiao,Y., G. Xie, C. Lu, X.Ding, Y.Lu. 2005. The value of gas exchange as a service by rice paddies in suburban Shanghai, PR China. Agriculture, Ecosystems \& Environment, 109(3-4): 273-283

Xudong, C., G. Yong dan F. Tsuyoshi. 2010. An overview of municipal solid waste management in China. Waste Management, 30(4), 716-724.

Yokohari, M., R.D.Brown, Y.Kato, H.Moriyama. 1997. Effects of paddy fields on summertime air and surface temperatures in urban fringe areas of Tokyo, Japan. Landscape Urban Planning, 38: 1-11.

Zhang,Q. and G. Wang. 2005. Studies on nutrient uptake of rice and characteristics of soil microorganisms in a long-term fertilization experiments for irrigated rice. J. Zhejiang Univ. Sci. B., 6(2): 147-154.

Zheljazkov,V.D. and P.R. Warman. 2004. Phytoavailability and fractionation of copper, manganese, and zinc in soil following application of two composts to four crops. Environmental Pollution, 131(2): 187-195. 